\title{
Contrasting effects of turf algae on corals: massive Porites spp. are unaffected by mixed-species turfs, but killed by the red alga Anotrichium tenue
}

\author{
Jamaluddin Jompa ${ }^{1,2,3}$, Laurence J. McCook ${ }^{2,4, *}$ \\ ${ }^{1}$ Department of Marine Biology, James Cook University, Townsville, Queensland 4811, Australia \\ ${ }^{2}$ Australian Institute of Marine Science and CRC Reef Research, PMB 3, Townsville, MC, Queensland 4810, Australia \\ ${ }^{3}$ Present address: Faculty of Marine Science and Fisheries, Hasanuddin University, Makassar 90245, Indonesia \\ ${ }^{4}$ Present address: Great Barrier Reef Marine Park Authority, PO Box 1379, Townsville, Queensland 4810, Australia
}

\begin{abstract}
Competition between corals and algae is an important process on coral reefs, especially during reef degradation, when abundant corals are often overgrown by benthic macroalgae. Despite the widespread assumption that macroalgae are able to out-compete corals for space, there have been very few experimental studies testing the nature of this interaction. This study compared the effects of a filamentous red alga, Anotrichium tenue, with those of mixed-species, filamentous algal turfs on massive Porites spp. corals on inshore reefs of the central Great Barrier Reef, Australia. We compared mortality of coral tissue in plots with $A$. tenue naturally present on live coral tissue, plots in which $A$. tenue was naturally present but experimentally removed, and plots where mixed algal turfs were naturally present but $A$. tenue was not. The results indicate that $A$. tenue killed coral tissue by active overgrowth. Removing the alga removed the effect. In contrast, general, mixed-species algal turfs did not cause any mortality of coral tissue. We suggest that 2 particular traits of $A$. tenue may facilitate its effects on the corals. First, unlike most filamentous turf species present, it was able to overgrow live coral tissue, perhaps due to allelochemical effects. Second, individual algal filaments trap relatively large amounts of mucus from the corals and of sediment, apparently increasing the damage to underlying coral tissue. Surveys indicated that $A$. tenue primarily affected massive Porites spp., that overgrowth effects were not site-specific, but that occurrence of infected corals was not widespread. In particular, distribution patterns were not consistent with an effect of terrestrial runoff. This study provides evidence of an exceptionally lethal effect on corals by a single species of filamentous alga, and emphasizes the species-specific nature of coral-algal competitive outcomes, even within a functional group.
\end{abstract}

KEY WORDS: Coral-algal competition $\cdot$ Anotrichium tenue $\cdot$ Epilithic algal community $\cdot$ Filamentous algal turfs $\cdot$ Porites spp.

Resale or republication not permitted without written consent of the publisher

\section{INTRODUCTION}

Competition between corals and benthic algae is centrally important to the structure and condition of coral reefs. Recent controversy over the relative importance of top-down (Hughes 1994, Hughes et al. 1999, Aronson \& Precht 2000) versus bottom-up (Lapointe 1997, 1999) factors in controlling macroalgal blooms during reef degradation has focused on the processes that control algal abundance. However, both perspectives tend to assume competitive superiority of algae over corals, whereby an increase in algal abundance will lead to a decrease in abundance of corals (McCook 1999). Despite the importance of algal competition with corals, there have been very few studies critically examining the nature of coral-algal interactions (McCook et al. 2001), and particularly few that unequivocally demonstrate competition as the cause of 
observed changes (e.g. discussed by Underwood 1986, McArdle 1996). In many cases, algal overgrowth may be the consequence, rather than the cause, of coral mortality or damage (Diaz-Pulido \& McCook 2002).

In a recent review (McCook et al. 2001), we suggested that available evidence indicates that coralalgal competition is widespread, but that the interaction is highly variable in both process and outcome, and should not be considered as simple or uniform. Several studies have shown negative effects of algae on corals (Hughes 1989, Coyer et al. 1993, Jompa \& McCook 2002), reducing coral growth, fecundity and recruitment (Tanner 1995, Miller \& Hay 1996, 1998). However, other studies have indicated slightly negative to neutral effects (Lirman 2001, McCook 2001) and one study even showed a positive effect, by reducing coral bleaching (Jompa \& McCook 1998). The interaction is not one-sided, as corals may inhibit algal growth or even overgrow the algae (de Ruyter van Steveninck et al. 1988, van Woesik 1998, McCook 2001, Jompa \& McCook 2002).

It appears that much of this variability can be understood in terms of the limited number of competitive mechanisms by which benthic algae can affect corals (McCook et al. 2001). Algal functional groups (Littler 1980, Steneck \& Watling 1982, Littler \& Littler 1984, Steneck \& Dethier 1994), based on the ecological properties and physical structure of the algae, are able to provide an effective summary of the competitive potential of different algae, based on the potential for those mechanisms. For example, filamentous algal turfs and canopy-forming leathery macrophytes have very different potential to inhibit corals. Canopy-forming macrophytes may effectively shade large areas of substrate but, having relatively small holdfasts, will not directly overgrow or smother significant areas of live coral tissue (McCook et al. 2001).

However, even within a functional group, there may be considerable differences in competitive potential between algal taxa. For example, filamentous algae have been reported both to overgrow and kill corals (Potts 1977, Littler \& Littler 1997), and to be overgrown and displaced by corals (McCook 2001), particularly during recovery from lesions (Bak et al. 1977, Meesters et al. 1994, van Woesik 1998). Early in 1999 we observed an unusually high number of massive Porites spp. colonies with patches of overgrowth by a single species of turfing, filamentous red alga (Anotrichium tenue) on the fringing reefs of the Palm Islands, Great Barrier Reef (GBR). This phenomenon provided an opportunity to compare the competitive effects of this species with that of the general, mixed-species filamentous turfs, thus allowing comparison within an algal functional group.

\section{MATERIALS AND METHODS}

Approach. This study describes the extent and process of Anotrichium tenue overgrowth and its effects on corals using a combination of several approaches. These comprised (1) a detailed description of the colonisation process at a small scale; (2) an experimental test to determine the extent to which $A$. tenue or mixedspecies algal turfs were the direct cause of mortality of coral tissue; (3) broader-scale observations, intended to establish the extent to which the patterns described in the more detailed work were site- or speciesspecific. These observations include: a comparison of the time course of overgrowth at 2 reefs; surveys of the occurrence of $A$. tenue overgrowth at a crosscontinental shelf scale; and surveys of the specificity of A. tenue infection to particular coral taxa.

Study sites. Most of the detailed monitoring work and the experimental study were conducted at 3 to $5 \mathrm{~m}$ depth on the reef slopes of the fringing reef at Cannon Bay, Great Palm Island, on the inshore central GBR (Fig. $1 ; 18^{\circ} 41.1^{\prime} \mathrm{S}, 146^{\circ} 35.2^{\prime} \mathrm{E}$ ). This site is located approximately $30 \mathrm{~km}$ from the coast and has approximately $20 \%$ cover of massive Porites spp., predominantly $P$. lobata, $P$. lutea and $P$. australiensis. The time course of Anotrichium tenue 'infection' at this site was compared to that at a site at Pioneer Bay, Orpheus Island $\left(18^{\circ} 36.4^{\prime} \mathrm{S}, 146^{\circ} 29.4^{\prime} \mathrm{E}\right)$ at approximately the same depth (3 to $5 \mathrm{~m}$ ). The latter site was dominated also by massive Porites spp. and is situated about $20 \mathrm{~km}$ from the coast. The frequency of $A$. tenue overgrowth was surveyed at 7 reefs across the continental shelf in the central section of the GBR (Fig. 1). Surveyed reefs ranged from those very close to the mainland and strongly influenced by terrestrial runoff (Goold Island and Pandora Reef, approximately $12 \mathrm{~km}$ offshore), through inshore (Orpheus Island and Great Palm Island) and mid-shelf reefs (Rib and Trunk, approximately $60 \mathrm{~km}$ from the coast) to the outer shelf (Myrmidon Reef, approximately $110 \mathrm{~km}$ from the coast), where terrestrial influence is minimal (for more detailed descriptions of the study reefs see Done 1982, Russ \& McCook 1999, McCook 2001).

Methods. Anotrichium tenue colonisation of live coral tissue-small-scale patterns: Description of A. tenue colonisation patterns involved monitoring changes in the area occupied by healthy, damaged and dead coral tissue, the area of $A$. tenue overgrowth, and the area of general, mixed-species algal turfs (Fig. 2A). A. tenue is usually pale pink or brown, the thallus sparsely branched, with most axes loosely prostrate (with erect axes of $\sim 0.5$ to $1 \mathrm{~cm}$ height) and attached to corallites by rhizoids (Fig. 2B). A. tenue overgrowth of massive Porites spp. usually occurred at the lower edge of the live coral tissue, forming distinct bands or 
Fig. 1. Map of central GBR showing study sites ranging from innermost inshore (Goold Island and Pandora Reef) reefs through inshore (Orpheus Island and Great Palm Island) to mid-shelf (Rib and Trunk Reefs), and outer-shelf (Myrmidon Reef) reefs. In comparison to mid- and outer-shelf reefs, inshore reefs are affected by relatively high inputs of terrestrial sediments and nutrients, with Goold Island strongly influenced by sedimentation and flood plumes from Herbert River (lightly shaded; further details in McCook 2001)

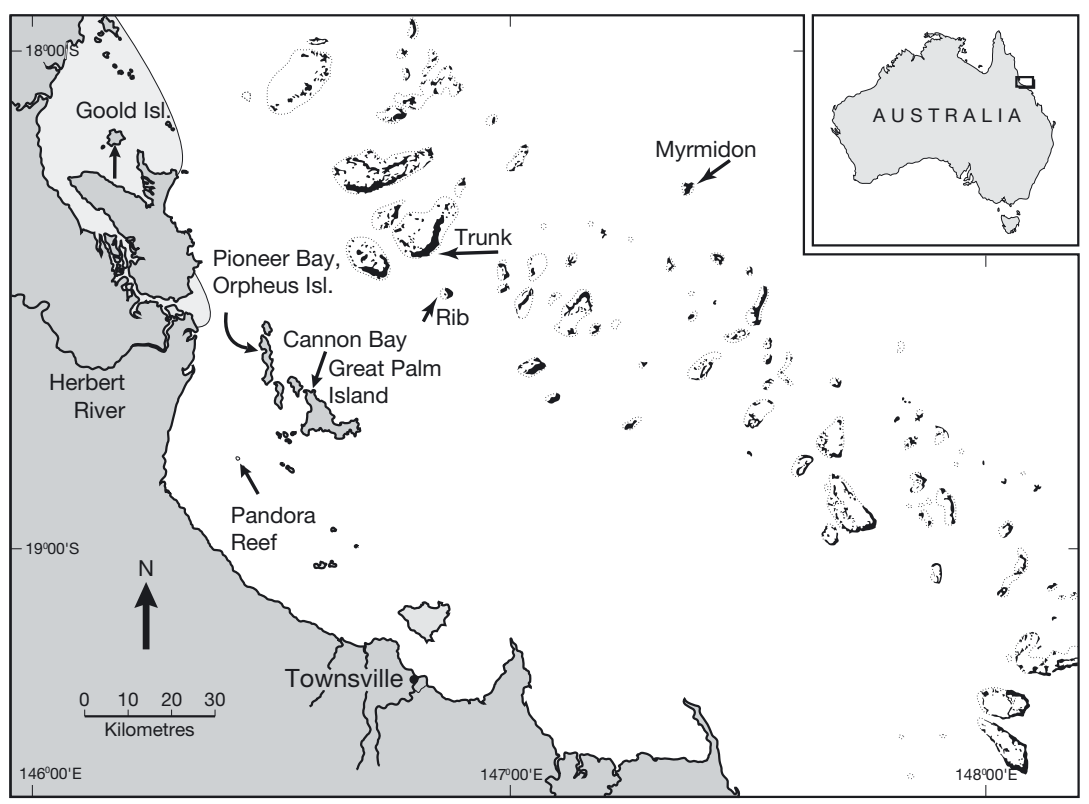

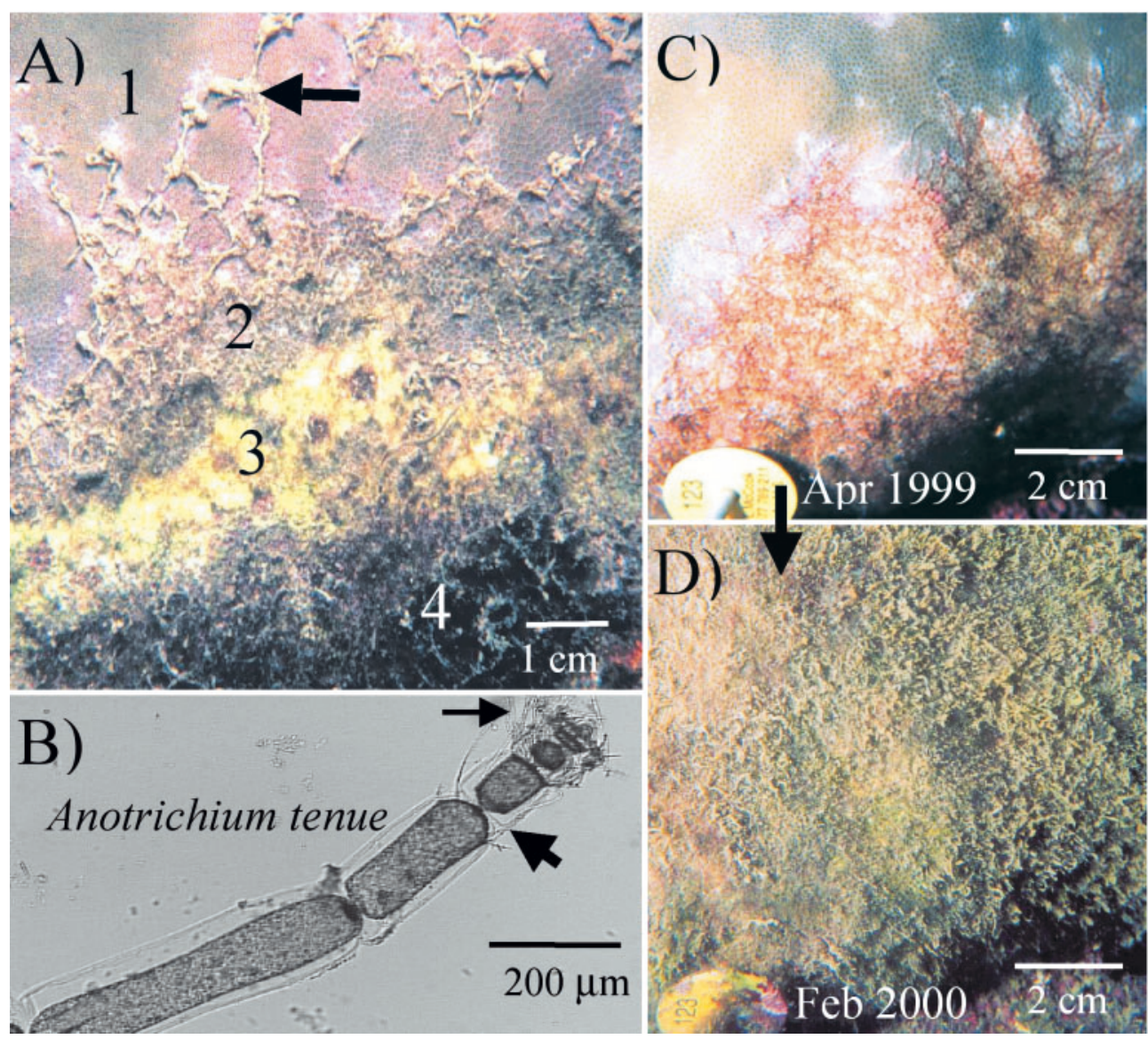

Fig. 2. Anotrichium tenue, a filamentous red alga, overgrowing the massive coral Porites spp. (A) Algal overgrowth forms 4 distinctive 'zones': (1) healthy coral tissue; (2) live coral colonised by A. tenue; (3) recently dead coral (bleached); (4) mixed algal turf. Observations of the time course, and experimental work, showed that the process involved active encroachment of $A$. tenue onto live coral tissue, causing coral death. Arrow shows single algal filaments trapping substantial quantities of sediment, apparently enhancing damage to underlying coral tissue. (B) Distinctive characteristics of an apical branch of $A$. tenue include transverse segmentation jointed with pit-connections (lower, thicker arrow) and trichoblasts around the apical cells (upper, thinner arrow). (C) Plot with $A$. tenue present in initial month, showing alga growing on live tissue of massive Porites, causing pale and bleached coral tissue, and encroaching toward healthy tissue. (D) Same plot (as in C) in final month, showing all coral tissue in plot overgrown by mixed algal turf 
zones (Fig. 2A). Descriptions are based on photographic monitoring of fixed plots, qualitative observations of wider areas, and microscopic identification of samples of algal turfs from within the relevant zones.

Effects of Anotrichium tenue and mixed algal turfs on corals-experimental test: The second approach involved an experimental test to determine the extent to which $A$. tenue actually caused damage or death of coral tissue, rather than simply overgrowing coral tissue damaged by some other unknown cause, and to compare the effects of overgrowth by $A$. tenue and general mixed-species algal turfs. The experimental design compared mortality of coral tissue in 3 treatments: (1) plots in which $A$. tenue was naturally present; (2) plots in which $A$. tenue was originally present but had been experimentally removed; and (3) plots in which mixed algal turfs were naturally present and $A$. tenue was not. Thus, any difference in coral mortality between the first 2 treatments could be assumed to be due to $A$. tenue overgrowth, and the third treatment provided a comparison with the more widespread general mixed-species filamentous algal turfs, indicating the extent to which any effect was specific to $A$. tenue.

Each treatment included 10 replicate small $(10 \times$ $10 \mathrm{~cm}^{2}$ ) plots located on massive Porites spp. colonies, chosen to include approximately $50 \%$ healthy coral tissue, and marked with nails and tags. We selected 20 plots to include Anotrichium tenue (e.g. Fig. 2C), 10 of which were randomly allocated to the $A$. tenue removal treatment and the rest left intact as controls (A. tenue present); 10 plots were also placed on the border between healthy coral tissue and mixed-turf algae overgrowing dead coral skeleton. Plots were generally on the lower side of the coral colony. The $A$. tenue removal treatment involved carefully removing the alga from the plots at the beginning of the experiment, either by hand or with a fine-pointed hobby knife, minimizing damage to underlying coral tissue. A. tenue did not generally recolonize the coral tissue following initial removal, so that subsequent algal removal was not necessary.

Plots were mapped in the field and monitored photographically at 5 dates over a period of 10 mo from April 1999 to February 2000. As Anotrichium tenue overgrowth generally formed 4 distinct zones (Fig. 2A), we estimated the area of (1) healthy coral tissue; (2) $A$. tenue growing on live coral tissue; (3) recently dead coral skeleton; and (4) mixed algal turfs. Areas were estimated from slides projected onto a $100 \mathrm{~cm}^{2}$ grid representing the $10 \times 10 \mathrm{~cm}^{2}$ plots, referring to fielddrawn maps where necessary. Data analysis was based on the change in percent cover of dead coral within each plot relative to cover at the initial date (i.e. $\%$ cover of dead coral tissue at each date minus \% cover of dead tissue on initial monitoring date in April 1999; referred to as 'mortality of coral tissue'). Dead coral tissue included recently dead coral skeleton and established mixed algal turfs (Zones 3 and 4 in Fig. 2A). Data were tested for treatment effects on the final date, using a 1-way ANOVA with treatments as a fixed factor, and Student-Newman-Keuls test $\left(\mathrm{SNK}_{i}\right.$ at $\mathrm{p}=$ 0.05). We also tested the significance of the changes through time using a paired $t$-test to compare initial and final cover of dead coral tissue in each plot. Data were examined for homogeneity of variance (Cochran's test), independence and normality of residuals (graphically).

Distribution and species-specificity-larger-scale patterns: To place the detailed and experimental work in a broader context, we examined 3 aspects of Anotrichium tenue overgrowth: the time course of overgrowth, the occurrence and frequency of overgrowth across the continental shelf, and the specificity of the overgrowth to massive Porites spp. The time course of overgrowth and extent of mortality of coral tissue was compared over 10 mo at 2 reefs (Cannon Bay, Palm Island, and Pioneer Bay, Orpheus Island) separated by about $15 \mathrm{~km}$. Ten plots with $A$. tenue present were established at Pioneer Bay, for comparison to the similar plots established at Cannon Bay. A Student's $t$-test was used to compare the mortality of coral tissue between the 2 sites after 10 mo (mortality calculated as detailed in preceding subsection).

Frequency of Anotrichium tenue overgrowth of live coral tissue was surveyed on 7 reefs across the continental shelf in the central section of the GBR (Fig. 1). Surveys involved 3 to 6 dives of approximately $1 \mathrm{~h}$ each around reef crests and slopes at all sites, recording frequency of occurrences and taxa of coral overgrown (numbers of massive Porites spp. colonies surveyed at each reef were at least 12 at Goold Island, 15 at Pandora Reef, 42 at Pioneer Bay, 40 at Cannon Bay, 25 at Rib Reef, 15 at Trunk Reef and 30 at Myrmidon; in total, approximately 107 patches of $A$. tenue were observed). Although $A$. tenue overgrowth is quite distinctive in appearance and easily distinguishable in the field (e.g. Fig. 2A,C), we collected samples of the alga for microscopic confirmation of the species identification.

\section{RESULTS}

\section{Anotrichium tenue colonisation of live coral tissue- small-scale patterns}

Observations and photo-monitoring showed that most live coral tissue overgrown by Anotrichium tenue eventually died. The time course of colonisation fol- 
lowed a fairly uniform pattern: A. tenue colonised live coral tissue, generally, but not always, at the boundary between dead coral skeleton and mixed algal turfs (Fig. 2A: Zone 2). The colonised coral tissue bleached and then died. A. tenue filaments disappeared from the dead coral tissue (Fig. 2A: Zone 3), apparently colonising adjacent, live coral tissue. The dead coral tissue was subsequently colonised by blue-green algae and 1 to 2 mo later by mixed-species filamentous algal turfs (Fig. 2A: Zone 4). Microscopic examination of algal specimens indicated that the recently dead area (Zone 3) was generally dominated by thin blue-green algae, including Schizotrix spp., Calothrix spp., Oscillatoriales and Coccogonales. Composition of the mixed algal turfs became similar to those on the mixed algal turf treatment plots, and were generally dominated by species of Polysiphonia, Cladophora, Centroceras, Sphacelaria, Hincksia, Ostreobium, Herposiphonia, with very little, if any, A. tenue.

Coral tissue overgrown by Anotrichium tenue was generally bright pink in colour, apparently a symptom of stress caused by the presence of the alga. We often observed substantial amounts of sediments and mucus adhering to individual filaments of $A$. tenue (Fig. 2A: arrow). Removal of this sediment sometimes revealed pale, bleached or dead coral tissue underneath. It appears that this trapped material may increase or accelerate the extent of coral tissue damage.

\section{Effects of Anotrichium tenue and mixed algal turfs on corals-experimental test}

Mortality of coral tissue was markedly and significantly higher in plots with Anotrichium tenue present than in plots from which $A$. tenue had been experimentally removed (demonstrating that $A$. tenue was in fact the direct cause of much of the damage to coral tissue) or in plots with general mixed-species algal turfs present (demonstrating that the effect was specific to A. tenue: Fig. 3, final month; Table 1; SNK). Cover of dead coral tissue in the plots with $A$. tenue present increased significantly over the 11 mo of the experiment (paired $t$-test $\mathrm{p}=0.0006$ ). In contrast, mortality was much less in the plots with $A$. tenue removed ( $\mathrm{p}=0.051$ ), and negligible in the plots with mixed species turfs $(\mathrm{p}=0.55)$.

Thus, relative to the general, mixed-species algal turfs, Anotrichium tenue was exceptionally effective at overgrowing and killing the coral tissue. The mixed algal turfs were relatively harmless to the corals. The slight increase in coral mortality in the $A$. tenue removal treatment at the end of the experiment was apparently caused by new $A$. tenue colonisation in 2 plots.

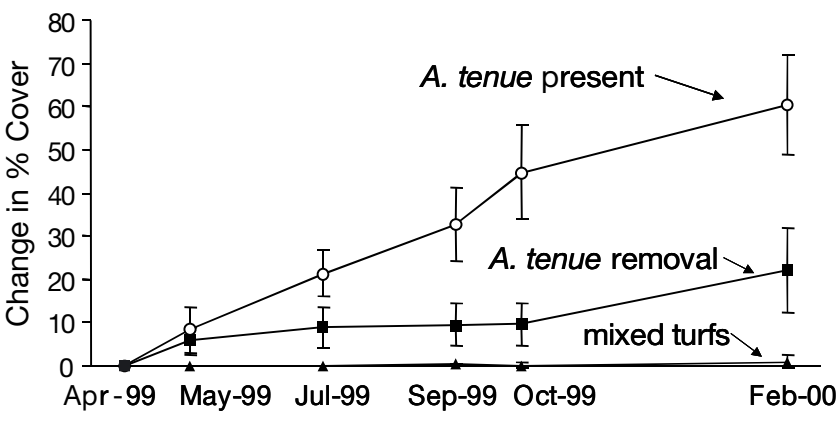

Fig. 3. Porites spp. Time course of mortality of coral tissue in each treatment at Cannon Bay, Great Palm Island. Data are changes in percent cover of dead coral tissue (Zones 3 and 4 in Fig. 2A) relative to initial monitoring month (i.e. final \% dead tissue minus initial $\%$ dead tissue; means $\pm \mathrm{SE}, \mathrm{n}=10$; because data are from $10 \times 10 \mathrm{~cm}$ quadrats, a $1 \%$ change corresponds to death of $1 \mathrm{~cm}^{2}$ coral tissue). Mortality of coral tissue was significantly higher in plots with Anotrichium tenue present than in the other treatments (Table 1 ; SNK test; $A$. tenue removal and mixed-turf treatments were not significantly different)

\section{Distribution and species-specificity_larger-scale patterns}

The overall time course of Anotrichium tenue overgrowth was very similar at Cannon Bay and Pioneer Bay (Fig. 4). Mortality of coral tissue at the end of the study was also similar for the 2 sites ( $t$-test: $\mathrm{p}=0.7$ ). $A$. tenue showed a general, gradual decline at both sites over the 10 mo period of the study, indicating that A. tenue patches are ephemeral, and persist for approximately 1 yr.

Surveys of reef crests and slopes indicated that $60 \%$ of the massive Porites spp. colonies at Cannon Bay and $40 \%$ of those at Pioneer Bay had patches of Anotrichium tenue overgrowth, with patches varying between 50 and $200 \mathrm{~cm}$ in length and up to $5 \mathrm{~cm}$ in width. In contrast, the phenomenon was relatively scarce at Pandora Reef ( $5 \%$ of colonies surveyed) and was not found at the very inshore reef (Goold) nor at the mid-shelf (Rib and Trunk) and outer-shelf (Myrmidon) reefs. The majority of corals observed with $A$. tenue overgrowing live tissue were massive Porites spp. (predominantly P. lobata, lutea and australiensis), although, much less frequently, the alga was also observed overgrowing live foliose Turbinaria spp., en-

Table 1. Porites spp. One-way analysis of variance of effects of treatment on mortality of coral tissue by final month (Fig. 3)

\begin{tabular}{|lrrrc|}
\hline Source & df & MS & $F$ & $p$ \\
\hline Treatment & 2 & 9094 & 11.62 & $<0.001$ \\
Error & 27 & 782 & & \\
\hline
\end{tabular}



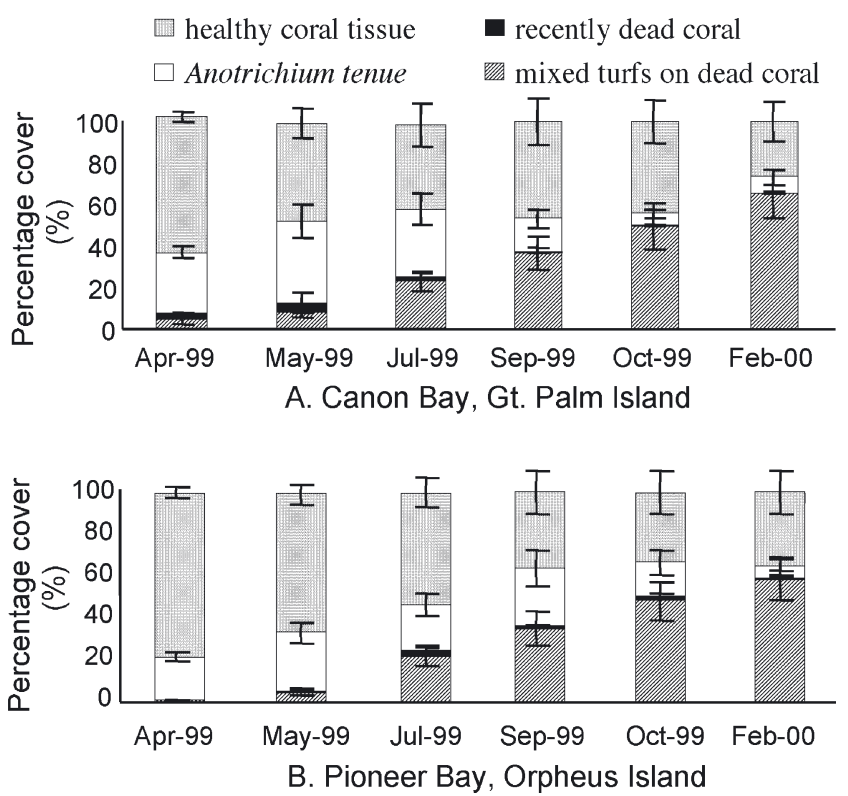

Fig. 4. Anotrichium tenue overgrowing Porites spp. Changes in percent cover for each zone (Fig. 2A) at Cannon Bay, Great Palm Island, and Pioneer Bay, Orpheus Island. Data are means $( \pm \mathrm{SE}, \mathrm{n}=10)$ for each zone

crusting to foliose Montipora spp. and branching $P$. annae. No other coral species were observed with A. tenue overgrowth, including the branching P. cylindrica, a widespread and abundant species in this area. Overgrowth appeared generally to develop at the border between the live coral and mixed algal turfs, although approximately $5 \%$ of $A$. tenue patches occurred completely within live coral tissue, suggesting that the alga was able to attach to live tissue either by settlement or by vegetative fragmentation. Massive Porites spp. colonies of up to $50 \mathrm{~cm}$ diameter were observed to have been completely killed, apparently by $A$. tenue overgrowth.

\section{DISCUSSION}

The combined small-scale observations and experimental results provide strong evidence that overgrowth by Anotrichium tenue is the direct cause of coral tissue death rather than simply a symptom or consequence of previous tissue damage or coral stress. Given the scarcity of experimental evidence for coralalgal competition (McCook et al. 2001), this study is significant simply as a clear demonstration of competitive overgrowth of live coral by a benthic alga.

However, this overgrowth also stands in strong contrast to the results for the general mixed-species algal turfs, which were not able to overgrow the live coral tissue in any of the plots. This suggests that these turfs were very poor competitors with the corals. Previous experimental work in this area (McCook 2001) showed that the presence of these mixed-species turfs was having little inhibitory effect on the corals, whereas the corals were inhibiting the algal turfs. The interpretation here, that the competitive ability of Anotrichium tenue is exceptional among the filamentous turfing algae (Figs. $3 \& 4$ ), is strengthened by the observations that (1) the general turfs are a mixture of a large number of species, none of which overgrew live coral tissue, and (2) the $A$. tenue patches have much lower biomass (per unit area) than the mixed turfs, yet are still much more effective competitors. Mixed turf colonisation generally followed coral tissue death caused by $A$. tenue, so that $A$. tenue appears to act as a colonizing species, in effect creating new substrate but subsequently being replaced by more typical turfs.

Thus it seems that the ability of Anotrichium tenue to overgrow and kill live coral tissue is exceptional and that, in general, filamentous algal turfs are not able to overgrow live coral tissue but are relatively poor competitors, having little effect on corals (McCook et al. 2001). Only 2 previous published studies have reported lethal effects of algal turfs on corals. Potts (1977) suggested that mixed-turf algae caused coral mortality as a result of the metabolic costs to the corals of removing sediments trapped by the turf algal mats. Littler \& Littler (1997) found that a non-filamentous but turf-forming macroalga Dasyopsis spinuligera overgrew corals in the Caribbean. They suggested that the likely mechanism involved was allelochemical or a secondary substance produced by the alga causing coral death. In contrast, most studies have reported minor effects of algal turfs on corals, or have even suggested that corals were competitively superior to the algal turfs (e.g. Fishelson 1973, Bak \& Steward-van Es 1980, Meesters et al. 1994, van Woesik 1998, McCook 2001).

It is useful to consider the mechanisms that might allow Anotrichium tenue to exert such exceptional effects on the corals. Two factors seem relevant, the ability to colonize live coral tissue despite defensive mechanisms by the corals (such as stinging, mucus secretion, etc.; Lang \& Chornesky 1990), and the ability to kill underlying coral tissue. Although we do not have direct evidence, it appears likely that both these abilities are facilitated by allelochemical substances produced by the alga, as the patterns of coral tissue death are not consistent with any of the other competitive mechanisms that enable algal overgrowth of corals (see Table 5 in McCook et al. 2001). Numerous other filamentous algae from the same family as $A$. tenue (the Ceramiaceae), with similar growth habits (i.e. creeping and branching, with erect axes and rhizoids; Price \& Scott 1992) were abundant among the mixed-turf algae at 
the study sites. However, only A. tenue was observed overgrowing massive Porites spp. corals. If the potency of $A$. tenue is chemically based, this would illustrate a limitation of the accepted functional groups of algae (Littler 1980, Steneck \& Dethier 1994) in describing competitive properties of algae (as suggested by McCook et al. 2001). These groups are based primarily on physical properties of the algae (height, density, toughness, etc.), and hence are less effective at explaining ecological properties which are chemically mediated.

Our observations also suggest that the extent of damage to coral tissue was significantly increased by the tendency of individual Anotrichium tenue filaments to trap coral mucus and/or sediments and detritus (e.g. Fig. 2A: arrow). By interfering with the cleaning mechanisms of the coral, the alga may cause stress to areas of tissue much larger than otherwise overlain by the relatively small algal filaments.

It is intriguing that Anotrichium tenue overgrowth was relatively specific, so that whatever the mechanisms involved, they appear effective for relatively few taxa of corals. This specificity is difficult to interpret, since it is not obviously related to either growth form or taxonomic affinities. Although most common on massive Porites spp., and recorded on the branching $P$. annae, we never recorded $A$. tenue on the branching P. cylindrica, which is widespread, and particularly abundant at Cannon Bay and Pioneer Bay. In contrast, we frequently observed another filamentous Ceramiaceae, Corallophila huysmansii, overgrowing P. cylindrica on these reefs, but did not find it on massive Porites spp. (Jompa \& McCook 2003, this volume). P. cylindrica has similar sized corallites $(\sim 1.5 \mathrm{~mm})$ to the massive Porites species studied here. Similarly, our observations of $A$. tenue on foliose, encrusting and branching corals are not consistent with a specificity to a particular life-form.

The combined results of the broader surveys and the comparison of overgrowth between sites suggest that the phenomenon is not widespread, but that the effects are not site-specific: wherever Anotrichium tenue overgrowth occurs, it is likely to have similar effects to those documented here. Although A. tenue was more abundant on live corals at Cannon Bay than at Pioneer Bay, the pattern of coral overgrowth was similar at both sites. A survey of algal turf settlement on inshore reefs in this area (authors' unpubl. data) indicated that A. tenue is not common in algal turfs, and was more common on Great Palm Island than on other islands in the Palm group, or on Goold Island. The species has also been reported from Malaysia (Masuda et al. 1999) and South Africa (Norris \& Aken 1985), and so is presumably widespread. Thus, although the results do not suggest that this alga poses a significant threat, as a pathogen, to coral populations at larger spatial scales, it is possible that the overgrowth phenomenon is quite widespread. A. tenue overgrowth was not recorded on either the reef most influenced by terrestrial runoff, nor the reefs most removed from such influences, suggesting that the phenomenon is unlikely to be related to anthropogenic changes in terrestrial runoff.

In summary, the results of this study demonstrate a marked contrast in competitive effects on corals between a single species of turfing, filamentous red alga, Anotrichium tenue, and a broad range of species with similar growth forms and even taxonomic affinities. The other species present in the general algal turfs at these sites were not able to colonize or significantly affect live tissue of massive Porites spp. colonies, whereas $A$. tenue was able to colonize live coral tissue, causing tissue death and serving as a colonizing species for general algal turfs. It appears that this competitive ability may be due to allelochemical or similar properties, but is limited to a relatively few coral taxa. The results illustrate the extent of variability in the processes and outcomes of coral-algal interactions, even within an algal functional group, algal family, and coral life-forms and genera. Although coral-algal competition may be widespread on coral reefs, the outcomes will vary considerably, and cannot be considered as a simple, uniform process.

Acknowledgements. We are indebted to G. Diaz-Pulido, C. Arango, A. Chin and a number of volunteers for considerable help with fieldwork, to I. R. Price for confirmation of algal identifications, and to G. Diaz-Pulido, H. Choat, T. Done, M. Miller, M. Littler and D. Littler for discussion. We acknowledge the use of the Australian Institute of Marine Science research vessels. The work was supported by AIMS, the CRC: Reef Research, School of Marine Biology \& Aquaculture, James Cook University, and an AusAID fellowship to J.J.

\section{LITERATURE CITED}

Aronson RB, Precht WF (2000) Herbivory and algal dynamics on the coral reef at Discovery Bay, Jamaica. Limnol Oceanogr 45:251-255

Bak RPM, Steward-van Es Y (1980) Regeneration of superficial damage in the scleractinian corals Agaricia agaricites f. Purpurea and Porites astreoides. Bull Mar Sci 30:883-887

Bak RPM, Brouns JJWM, Heys FML (1977) Regeneration and aspects of spatial competition in the scleractinian corals Agaricia agaricites and Montastrea annularis. Proc 3rd Int Coral Reef Symp 1:143-148

Coyer JA, Ambrose RF, Engle JM, Carroll JC (1993) Interactions between corals and algae on a temperate zone rocky reef: mediation by sea urchins. J Exp Mar Biol Ecol 167: $21-37$

de Ruyter van Steveninck ED, Van Mulekom LL, Breeman AM (1988) Growth inhibition of Lobophora variegata (Lamouroux) Womersley by scleractinian corals. J Exp Mar Biol Ecol 115:169-178

Diaz-Pulido G, McCook LJ (2002) The fate of bleached corals: patterns and dynamics of algal recruitment. Mar Ecol Prog Ser 232:115-128 
Done TJ (1982) Patterns in the distribution of coral communities across the central Great Barrier Reef. Coral Reefs 1:95-107

Fishelson L (1973) Ecological and biological phenomena influencing coral-species composition on the reef tables at Eilat (Gulf of Aqaba, Red Sea). Mar Biol 19:183-196

Hughes TP (1989) Community structure and diversity of coral reefs: the role of history. Ecology 70:275-279

Hughes TP (1994) Catastrophes, phase shifts, and large-scale degradation of a Caribbean coral reef. Science 265: $1547-1551$

Hughes TP, Szmant AM, Steneck R, Carpenter R, Miller S (1999) Algal blooms on coral reefs: what are the causes? Limnol Oceanogr 44:1583-1586

Jompa J, McCook LJ (1998) Seaweeds save the reefs?!: Sargassum canopy decreases coral bleaching on inshore reefs. Reef Res 8:5

Jompa J, McCook LJ (2002) The effect of herbivory on competition between a macroalga and a hard coral. J Exp Mar Biol Ecol 271:25-39

Jompa J, McCook LJ (2003) Coral-algal competition: macroalgae with different properties have different effects on corals. Mar Ecol Prog Ser 258:87-95

Lang JC, Chornesky EA (1990) Competition between scleractinian reef corals - a review of mechanisms and effects. In: Dubinsky Z (ed) Ecosystems of the world: coral reefs. Elsevier, Amsterdam, p 209-252

Lapointe BE (1997) Nutrient thresholds for bottom-up control of macroalgal blooms on coral reefs in Jamaica and southeast Florida. Limnol Oceanogr 42:1119-1131

Lapointe BE (1999) Simultaneous top-down and bottom-up forces control macroalgal blooms on coral reefs (reply to the comment by Hughes et al.). Limnol Oceanogr 44: $1586-1592$

Lirman D (2001) Competition between macroalgae and corals: effects of increased algal biomass on the survivorship and growth of the Caribbean corals Siderastrea siderea, Porites astreoides, and Montastrea faveolata. Coral Reefs 19:392-399

Littler MM (1980) Morphological form and photosynthesis performances of marine macroalgae: tests of a functionalform hypothesis. Bot Mar 22:161-165

Littler MM, Littler DS (1984) Relationships between macroalgal functional form and substrata stability in a subtropical rocky-intertidal system. J Exp Mar Biol Ecol 74:13-34

Littler DS, Littler MM (1997) Epizoic red alga allelopathic? to a Caribbean coral. Coral Reefs 16:168

Masuda M, Abe T, Kawaguchi S, Phang SM (1999) Taxonomic notes on marine algae from Malaysia. I. Six species of Rhodophyceae. Bot Mar 42:449-458

Editorial responsibility: Antony Underwood (Contributing Editor), Sydney, Australia
McArdle BH (1996) Levels of evidence in studies of competition, predation, and disease. NZ J Ecol 20:7-15

McCook LJ (1999) Macroalgae, nutrients and phase shifts on coral reefs: scientific issues and management consequences for the Great Barrier Reef. Coral Reefs 18:357-367

McCook LJ (2001) Competition between coral and algal turfs along a water quality gradient in the nearshore central Great Barrier Reef. Coral Reefs 19:419-425

McCook LJ, Jompa J, Diaz-Pulido G (2001) Competition between corals and algae on coral reefs: a review of available evidence and mechanisms. Coral Reefs 19:400-417

Meesters EH, Noordeloos M, Bak RPM (1994) Damage and regeneration: links to growth in the reef-building coral Montastrea annularis. Mar Ecol Prog Ser 112:119-128

Miller MW (1998) Coral/seaweed competition and the control of reef community structure within and between latitudes. Oceanogr Mar Biol Annu Rev 36:65-96

Miller MW, Hay ME (1996) Coral-seaweed-grazer-nutrient interactions on temperate reefs. Ecol Monogr 66:323-344

Miller MW, Hay ME (1998) Effects of fish predation and seaweed competition on the survival and growth of corals. Oecologia 113:231-238

Norris RE, Aken ME (1985) Marine benthic algae new to South Africa. S Afr J Bot 51:55-65

Potts DC (1977) Suppression of coral population by filamentous algae within damselfish territories. J Exp Mar Biol Ecol 28:207-216

Price IR, Scott FJ (1992) The turf algal flora of the Great Barrier Reef. Part I. Rhodophyta. James Cook University of North Queensland, Townsville

Russ GR, McCook LJ (1999) Potential effects of a cyclone on benthic algal production and yield to grazers on coral reefs across the central Great Barrier Reef. J Exp Mar Biol Ecol 235:237-254

Steneck RS, Dethier MN (1994) A functional group approach to the structure of algal-dominated communities. Oikos 69:476-498

Steneck RS, Watling L (1982) Feeding capabilities and limitations of herbivorous molluscs: a functional group approach. Mar Biol 68:299-319

Tanner JE (1995) Competition between scleractinian corals and macroalgae: an experimental investigation of coral growth, survival and reproduction. J Exp Mar Biol Ecol 190:151-168

Underwood AJ (1986) The analysis of competition by field experiments. In: Kikkawa J, Anderson DJ (eds) Community ecology: pattern and process. Blackwell Science, Melbourne, p 240-268

van Woesik R (1998) Lesion healing on massive Porites spp. corals. Mar Ecol Prog Ser 164:213-220

Submitted: May 22, 2001; Accepted: February 7, 2003

Proofs received from author(s): August 4, 2003 